\title{
Contributions of Non-Governmental Organisations to Women's Participation in Local Governance in the Tamale Metropolis of Ghana
}

\author{
Roland Adatuu \\ University for Development Studies, Tamale \\ George Gyader \\ (Corresponding author) \\ Department of Social Political and Historical Studies, FIDS \\ University for Development Studies, Wa Campus \\ phaceg@yahoo.com \\ DOI//http://dx.doi.org/10.4314/gjds.v16i2.4
}

\begin{abstract}
In Ghana there are many legal documents and actions seeking to advance women's participation in governance at the local and national levels. For instance, the Constitution of the country frowns on any discrimination against women. Ghana has also been a primary signatory and has ratified a number of conventions and declarations such as the current Sustainable Development Goals. Despite these efforts, women still lag behind men in terms of their numbers and level of participation especially in local governance. Recently, certain non-governmental organisations, including the Northern Sector Action on Awareness Centre, Campaign for Female Education and Action Aid Ghana, have taken the lead in the Tamale Metropolis to champion the course (financing, educating and training) of women in participating at the local level of the governance process. A cross-sectional observation of the target group of people was supplemented with questionnaire, key informant interviews and focus group discussions as data collection tools. Data analysis was both qualitative and quantitative. The paper concludes that Non-Governmental Organisations (NGOs) contribution to the participation of women in local governance in the Tamale Metropolis. Recommendations included provision of a conducive environment and promotion of education and training for women.
\end{abstract}

Keywords: Participation, NGOs, Women, Governance, Politics 


\section{INTRODUCTION}

Increasingly, women play an important role towards social, political, cultural and economic development. This has received enormous recognition and attention globally. It has also been the same recognition given in the discourses of the national development context of Ghana. The contribution of women to national development through their participation in local governance has been acknowledged. Since independence, women have always been recognised for their contribution to national development till date. In 2001 especially, a special Ministry was created to specifically address the concerns of women and children in Ghana.

This issue of women in development and its effective implementation or practice continues to be discussed at the local level. To this end, efforts have been made not only towards the welfare of women, but also to bridge the gap in terms of their participation in formulating decisions which most affect their lives, more especially in the periphery. Locally, ABANTU for Development in Ghana among others advocated women's participation not only for equality, but equitably in local governance. Despite these ground breaking efforts, evidence in Ghana suggests that women do not have a full complement of representation in local level governance like their men counterparts.

It is amidst this rather beguiling situation that Non-governmental Organisations (NGOs), such as, the Northern Sector Action on Awareness Centre (NORSAAC), Campaign for Female Education (CAMFED) and Action Aid Ghana have marshalled forces to support women to participate at the grass-root level in the Tamale Metropolis. This study thus, interrogates the extent of the contributions these NGOs make to support the participation of women in the Tamale Metropolis.

Findings reveal a more level of awareness of women about the need for their participation in the local level decision making processes. Women are now more determined to let their voices be heard in the structures at the local level that provide the opportunity. Some recommendations from the study include: promotion of favourable environment for women to contest in more elections; and promoting the education and training of women in the Tamale Metropolis.

\section{LITERATURE REVIEW}

Internationally, nationally and locally, women's contribution toward deepening the democratization process has been well documented. However, more women than men lag behind in terms of their participation in structures that provide the opportunity in politics and decision-making. Ocran (2014) captures succinctly that 
averagely, women only constitute 21.8 Percent of the world's national parliaments. He describes this as lagging behind the threshold of 30\% which was provided in the Beijing Platform for Action at the Fourth World Conference in 1995.

Similarly, Shamim and Kumari (2002), Hamah (2015), Adatuu (2017) and Shiraz (2015) examining the issue more specifically show that although women had and have been occupying high positions in government globally and nationally, the statistics tell a different story. Ihemeje (2013) for instance argued that a threshold of $30 \%$ representation of women is yet to be achieved the world over as well as at the national and local levels of governance. Agbalajobi's (2009) study corroborates Ihemeje's (2013) assessment of the low representation of women in local governance structures. He clearly stated that this is just not a continental issue, but a global challenge as well.

The World Bank (2001) has shown that in least developed areas especially, most women are yet to be accorded the same basic rights as men do. This issue is particularly much worrying in Africa. In Ghana, just as in the case of Nigeria, Baveng (2011) and Quansah and Essien (2014) have also agreed that women have low participation at the grass-root level. Women in Ghana are generally underrepresented in political life and in decision making.

Studies (Ofei-Aboagye, 2000; Apusigah \&Adatuu, 2017; Abubakari, Mohammed \& Issah, 2014) have shown that while the visibility of women in higher and lower levels of governance in Ghana has seen marginal increases in recent times, for instance, women who contest for the District Assembly (DA) elections saw an increment by 79 percent from 547 in 1994 to 981 in 2002 and the numbers of women who were elected also saw an increment from 124 to 341 representing 75 percent increment within the same time frame(Ofei-Aboagye, 200o), the numbers are still woefully inadequate. Apusigah and Adatuu (2017) have equally noted that despite the favourable political environment during independence for increasing women in decision making at the lower and national levels, the number of women has rather been disappointing.

Quansah and Essien (2014) particularly show that in the Tamale Metropolitan Assembly (TAMA), numbers of elected women since the start of the decentralization concert did not one (1). Particularly, some positions at the Assemblies are by appointment. It would therefore been easy for government to at least appoint 50\% of women to occupy these seats. In TAMA, the total number of women membership is only 9 (9.8\%) out of 92 in the 2010-2014 period. In the 1st September, 2015 District level elections, the entire Northern Region recorded low numbers of elected women in the assemblies. The Region had only 18 elected women out of the 705 elected 
members. This necessitates the question: why should women have such a poor representation and participation in TAMA? In the light of the above, the research questions the paper interrogates are: What contributions do NGOs make to support women to participate at the local level in the Tamale Metropolis? To what extent do women participate in local governance in the Tamale Metropolis? What are the challenges to women's participation in the local structures of governance in the Tamale Metropolis? In the ensuing sections, a literature review is made on participation, arguments to support the political participation of women, NGOs, women and local governance followed by conclusion and recommendations. But first, here is the methodology of the study.

\section{FIELD DESCRIPTION AND OBSERVATION}

Tamale is the capital of the Northern Region and it is home to many political activities. The city has also been recently seen to be one of the fast growing cities in the sub-region. Since the beginning of the local government system in 1988, the city has had its share of electing leaders to take up the mantle to make decisions for the Metropolis. However, this has been done on a male-centric basis. Women have been consistently outnumbered by their male counterparts during elections and appointments to the Tamale Metropolitan Assembly. Since 1988, Mahamadu (2010) has argued that TAMA has continuously witnessed low numbers of women representation in it. This has drawn the attention of non-governmental organisations to intervene to address the situation. A cross-sectional survey was carried out in the Metropolis. Probability and non-probability techniques of sampling were adopted and used in this research. Purposive sampling was used to recruit 75 men and 75 women of voting age who were Assembly Members (26), Town Councils members (2), Area Councils members (2), Unit Committee members (70) and 50 NGO staff. First, the respondents were 18 years and above and second, they were assembly, town, area council or unit committee members and staff of NORSAAC, CAMFED and ActionAid Ghana in Tamale. The assembly, town, area council or unit committee members were then randomly selected through balloting their names and then the final sample was drawn from the ballot till the required number of participants were obtained for the questionnaire. The staff of the NGOs was selected purposively that is only NGO staffs that were directly involved in projects that provided support to women's participation in local governance were contacted and interviewed. The researchers visited the offices of the NGOs, requested and met such staff for the questionnaire administration. Also, men and women knowledgeable in the study area were selected for the KIIs and FGDs. In all, 150 women and men were selected for the questionnaire. There were seven (7) KIIs 
(4 women and 3 men) and seven (7) FGDs comprising eight women and men each giving a total of 56 for the FGDs.

Data analysis took the form of qualitative and quantitative analysis. The qualitative analysis adopted descriptions and narrations interposed with some discussions on the field data from the Metropolis. Themes were derived from the research objectives and questions constituting the major headings in the analysis. For the quantitative analysis, the Statistical Package for Social Scientists (SPSS) software enabled to generate some tables and figures and descriptive explanations followed the tables and figures.

\section{Conceptualising the Participation of Women in General}

Khan and Ara (2006) have stated that the term 'participation' is one of the development approaches, which sees the needs involving vulnerable, marginalised and disadvantaged people in the design of policies and implementing those policies that affect their lives. Yartey (2012) opines that the concept of participation is relevant in a society's development whether it is big or small, an oligarchy or democracy. Decisions must be taken if society must progress.

Rahman (1991), states that when citizens get the opportunity to be involved in the administrative process is what is actually called 'participation'. Citizens taking part can be at two levels that is the micro and macro. It can also be in the form of advisory or decision making. At another level, it can be at the implementation level. Parry, Mosley and Day (1992) see participation in the form of a process that involves a citizen being part in what is called a process of forming, passing and implementation of public policies.

All the conceptualisations of 'participation' can be subsumed as: the involvement of vulnerable, marginalised and disadvantaged population in forming, passing and implementing policies that may directly or indirectly affect their lives.

It is notable that in many African societies, culture and traditions can either directly or indirectly affect how some of the citizens are either included or exclude some people in taking part of decisions at the community level. However, literature in the field nearly neglects some of these important issues that really affect participatory decision making. Sometimes, issues of these nature have helped to give women a low representation in local government structures in Ghana since 1994.

In Northern Ghana, the participation of women in MMDAs is disappointing. In the 2015 District level election for, instance, out of the 705 persons who contested elections, only18 were women in the Northern Region, 7 in Upper East Region out 
of 376 elected members and 9 in the Upper West out of 293 elected members. Table 1 shows the number and percentage of women elected in Northern, Upper East and Upper West Regions of Northern Ghana in 2015.

Table 1: Number and percentage of women elected in Northern, Upper East and Upper West Regions of Northern Ghana in 2015

\begin{tabular}{|l|l|l|l|}
\hline Region & $\begin{array}{l}\text { Number of Elected } \\
\text { Members }\end{array}$ & $\begin{array}{l}\text { Total Number Contested } \\
\text { (men and women) }\end{array}$ & Percentage \\
\hline Northern Region & 18 & 705 & 2.6 \\
\hline Upper East Region & 7 & 376 & 3.5 \\
\hline Upper West Region & 9 & 293 & 3.1 \\
\hline 1Total & 34 & 1374 & 9.2 \\
\hline
\end{tabular}

Source: Adopted and modified from Awal (2015)

Table 1: indicates that for the 2015 District level election in Ghana, out a total of 1374 men and women contestants, only 34 were elected as women in the three Regions of the North. This number (34) makes only a paltry of $9.2 \%$ of the total number of women elected to the MMDAs in the Regions.

\section{Barriers to Women's Representation and Participation in Local Governance in Tamale Metropolis}

The Women's Manifesto for Ghana (2004) observed that the challenge to the participation and representation of women in lower level of decision making had historical antecedents dating back as far as 1988. This has persisted till date making it a top priority in Ghana if the deepening and consolidation of Ghana's democracy is to be achieved and if the development of the country must be accelerated at a rapid pace.

Offei-Aboagye (2000), Allah Mensah (2005) and Amoako (2011) have long known that inadequate finance for campaigning, time for managing household chores and the unavailability of some income-generation activities for women hinder their political fortunes. It is also widely known that politics is a "dirty" game and not an arena for women to engage in. These prevent women from venturing into such corridors.

Amoako (2011:5) equally noted that, low literacy among women affects their participation at the district assembly level negatively. She asserted that "The low educational level of most of the women candidates was also identified as a major setback in leadership, hence, the poor performances of women." 
According to Adatuu (2017), religion hinders women's representation and participation in decision-making and politics in Tamale, Bolgatanga and Wa. The issue, the author emphasises, is more acute in Tamale than in Bolgatanga and Wa. The author notes that the Islam is especially a major challenge. According to Adatuu (2017), Islam bars women in the Tamale Metropolis from seizing an opportunity to leadership. Women necessarily need to obey men. This is demonstrated in how prayers are organised in the Mosque. During prayers, women remain in the back, while men lead. So it is with politics. It is the arena of men.

Dolphyne and Ofei-Aboagye's study (2001) corroborates Adatuu's (2017) findings. These authors assert that Christian fundamentalism prevents women from actively participating in decision - making and politics in the southern part of Ghana, while in northern Ghana it is Muslim fundamentalism.

Explaining further, Deku (2005: 120) states that it is time when the mind-set that "every woman is inferior to any man" needs a change. Thus, values that are empowering are instilled in the male while values that are disempowering are instilled in the female. Even women themselves have been brainwashed into accepting this situation and sometimes mistake absolute male protection as a privilege.

In spite of the challenges that have bedevilled women in their representation, one would have thought that the few who are represented would have been given ample opportunity to effectively participate in the decision making processes. This is not the case! According to Offei-Aboagye (2000: 4), "Inside the assembly, women have yet to make their presence felt. In spite of the increases in their numbers provided for by the government directive, their performance has been muted."

\section{Extent of Women's Participation in Local Governance in the Tamale Metropolis}

Abubakar et al. (2014) aver that considerable efforts for the participation of women in Ghana are visible nationally and locally. Women participated in local level elections in the Tamale Metropolis. An overwhelming majority of 135 (90\%) respondents indicated that women participated in local governance. The respondents mentioned the number of women they knew who participated in local governance. Those who mentioned 1-15 women were 76 (50.7\%), those who mentioned 16-30 women were 70 (46.7\%) while those who mentioned 31 and above were only $4(2.7 \%)$ respondents. This shows that there are fewer women in local governance as the number that mentioned the number of women above 30 were only few. This supports Mahamadu's (2010) assertion. Mahamadu's (2010) states 
that in the 2010 elections, of the 17 women who contested the elections, only one (1) was elected to the 64 elected-member assembly. With this abysmal situation, it was expected that the government would increase the tally of women by giving at least $40 \%$ of appointed positions to women; but only eight (28\%) women were appointed among the 28 government appointees.

Women participate more at the assembly level than any other local governance structure that provides the opportunity. Seventy-nine (51.3\%) of the respondents mentioned that it is at the assembly level which women participate more in local governance. Seventy one (47.3\%) respondents mentioned the unit committee while only 2 (1.3\%) respondents mentioned the town/area council. Figure 2 shows the structure in which more women participate in local governance.

\section{Figure 1: The structure in which more women participate} in local governance in the Tamale Metropolis

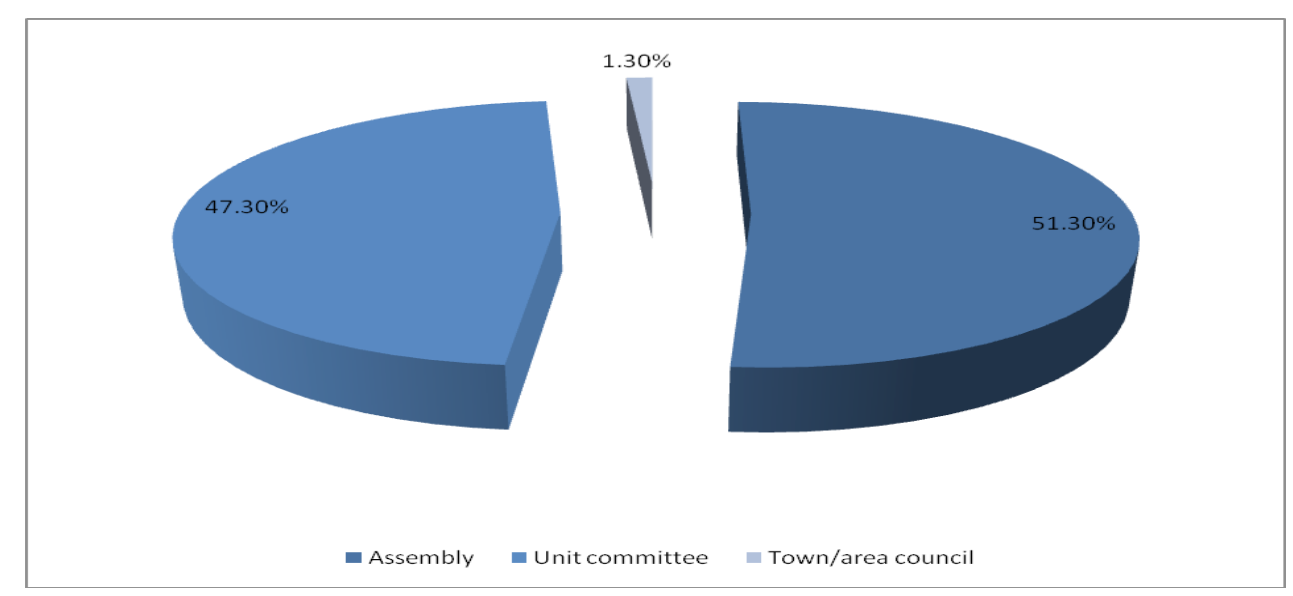

Source: Field data (2017)

Figure 2 indicates that majority of the respondents $51.3 \%$ knew that women participated highest at the assembly level. The next structure that the women participate high is the unit committee (47.3\%) and the last structure that women participate is the town/area councils (1.3\%). This contradicts popular thinking while evidence from other districts suggests that the unit committee which services as a basic unit of local government has more women than the assembly (see Adatuu and Apusigah, 2017). 


\section{Challenges Hindering Women's Participation in Local Governance within Tamale Metropolis}

\section{Financial Constraints}

Offei-Aboagye (2000), Allah Mensah (2005) and Amoako (2011) have all argued for the limitations of financing posed on women in their attempt to be involved in the politics of campaigning at the local level of the Tamale Metropolis. Lack of access to economic resources by women affects them in their bid to participate in politics and governance at the local level. Seventy seven (51.3\%) of the respondents stated this. The implication is that financial constraints, such as, money prevents women from participating in local governance in the Metropolis.

\section{Lack of Self-Confidence}

Deku (2005:120) asserts that it is about time to change to change the thinking that supports the notion that every woman was inferior to any man. In the Ghanaian societal context, right from the formative years following from birth there is a lingering perception instilled in young children on the idea of male superiority over their female counterparts. Thus, values that are empowering are instilled in the male while values that are disempowering are instilled in the female. Even women themselves have been brainwashed into accepting this situation and sometimes mistake absolute male protection as a privilege.

The study indicated that women in the Tamale Metropolis lack self-confidence to vie for public positions in local government structures due to their orientation as household keepers. Majority of the respondents, 134 (89.3\%) mentioned that women in the Tamale Metropolis lack self-confidence when it comes to competing for public office. In a KII with a NGO staff, she stated that:

The mind set of society: prejudice arising out of culture and traditions hinder - the proper participation of women in the local governance of their environment - especially in this region because society till date still thinks that the right place for a woman is the home.

Even those who secure positions have not been effective. Offei-Aboagye (2000:4) observes that "Inside the assembly, women have yet to make their presence felt. In spite of the increases in their numbers provided for by the government directive, their performance has been muted. This has been attributed to lack of self-confidence..." In another KII with an - NGO advocating for women's participation in local level governance staff, he said: "Society is not yet ready to have women as leaders: stereotyping and the perception arising out of culture those 
women cannot prove themselves as worthy leaders makes it impossible for participation by women in governance at the local level over here."

\section{Inadequate Political Skills and Knowledge}

Offei-Aboagye (2000), Allah Mensah (2005) and Amoako (2011) have all lamented on the apparent lack of voting for women contestants as it was thought that the domain of politics belonged more to men than women. Consequently, women are perceived as lacking the needed knowledge and skills to sail the ship of political affairs at the local level. About one hundred (making 66.7\%) of respondents stated poor political skills and knowledge as a major constraint for women's participation in decision making in the Tamale Metropolis. In this context, Offei-Aboagye (2000), Allah Mensah (2005) and Amoako (2011) also found that women lack public arena skills and some complain of intimidation by male opponents.

\section{Women's Household Responsibilities}

Women's household responsibilities affect their ability to contest for public office at the rural and local level. One hundred (66.7\%) respondents indicated that women contestants have many household responsibilities to discharge and hence, it has left them with little time to venture into governance activities in the public arena. Implying that woman's responsibilities as wives, caretakers and administrators of the household affect their ability to contest and occupy public office of decision making in the Tamale Metropolis.

\section{Women Lack Support from their Colleague Women}

The study showed that women in the Tamale Metropolis lack support from their colleagues when they want to seek public office. This affects their active participation in governance at the local level in the Metropolis. Eighty-two (54.7\%) of the respondents stated that women lack support from their colleague women when they seek political office.

\section{Limited Government Support}

Ghana's 2004 Women's Manifesto, noted that, the challenge of low women representation in local level government roles had existed as far back as 1988. It further observed that the problem had persisted and from all indications would continue to be of top most priority in Ghana if government wanted to accelerate, deepen and consolidate Ghana's democracy at a rapid pace. 
In line with the above, the study further established that women in the Tamale Metropolis have limited government support to enable them participate in local level decision making and politics. These findings corroborated Mahamadu's (2010) study at the local level of the Assembly that established that TAMA has consistently experienced very low women's representation since 1988. The first assembly had only one (1) elected woman out of 54 and no appointed woman among the 22 government appointed members. Similarly, the two assembly periods of 1994-1998 and 1998-2002 each had one (1) elected and five (5) appointed women.

\section{Religion}

Adatuu's (2017) study found out that religion affects the participation of women in politics in the three northern regional capitals. Furthermore, the findings of the study showed this to be more acute in Tamale than in the other two regions. The Islamic religion was thought to be a major factor. From a focus group discussion with Moslem women in the Tamale Metropolis, it was realised that their religion bars them from positions of leadership. A woman has to be subjective to the man. This was even demonstrated by how prayer positions are organised in the Mosque. During prayers, the women remain in the back while men lead. Likewise, politics was considered a domain of men and ladies supported from behind their male counterparts.

Additionally, the study of Dolphyne and Ofei-Aboagye (2001) corroborated the above. They identified Christian fundamentalism contributed to preventing women from active participation in politics in southern Ghana, while in the northern part, it was Muslim fundamentalism (Dolphyne and Ofei-Aboagye, 2001).

Religion is a strong factor that limits the chances of women candidates winning and getting appointed to the assembly in Tamale. One hundred and ten (73.3\%) agreed that religion was main factor influencing female chances of contesting, being involved and getting elected or being appointed to local level governance structures such as the Tamale Metropolitan Assembly. Religious values and related consideration therefore comes up as a strong factor limiting the full participation of women at the local of TAMA.

\section{Women's High Illiteracy}

In this context too, Amoako (2011:5) work argued that low literacy among women affects their participation at the district assembly level negatively. The study identified 'the low educational level of most of the women was another major setback in leadership status for women. It established that the poor performance of women in general was in part due to the illiteracy among women in the Tamale 
Metropolis', thus affecting the participation of women in local governance negatively. Seventy-five (50\%) of the respondents stated this in their responses.

\section{Some Mitigation Measures to Help Remove Challenges Hindering Effective Women Involvement in Local Governance}

This study shows that women themselves can contribute to remove the challenges that hinder their participation in local governance in the Tamale Metropolis. An overwhelming majority, 130 (86.7\%) of the respondents have said that women are capable of working themselves to eliminate the obstacles that hinder their effective participation in local governance in the Metropolis.

One way women can boost their self-confidence is to avail themselves to educational and training opportunities. This will remove the inferiority and shyness that characterise low self-confidence. Forty (26.7\%) of the respondents stated this.

Eighty (53.3\%) of the respondents said that women should dialogue and collaborate with one another more intensely find ways to mobilise resources and awareness campaigns to enable them overcome the challenges to their participation. They should remove all forms of jealousy and envy, which makes them their own enemies. Thirty (20\%) of the respondents' stated that women already in local governance should mentor their colleague women outside of local governance system to enable more women participate in local governance. Figure 3 shows the mitigation measures women can employ to remove the hindrances to their participation in local governance.

Figure 2: Mitigation measures women can employ to remove the challenges to their participation in local governance

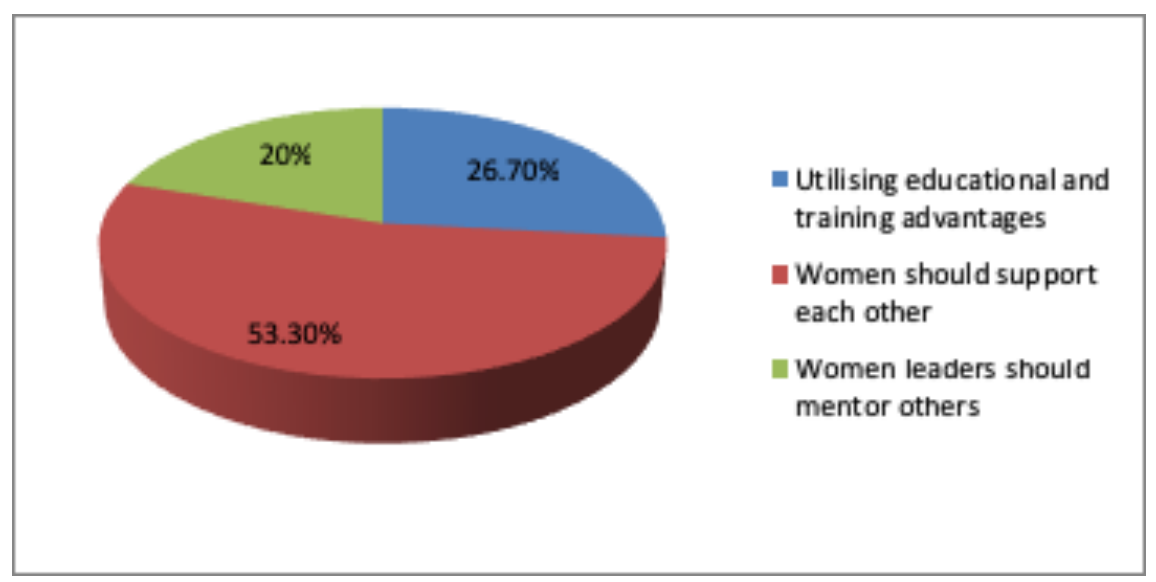

Source: Field data (2017) 
Figure 2 indicates that majority of the respondents have stated that financing is key to women in terms of resources and in times of electoral campaigns if they are change the fortunes of their effective involvement. Women also need to take advantage of educational and training opportunities that build their capacities on elections and the electoral processes in the country. In addition to that women already occupying positions in local government should make it a duty to mentor others outside who have the interest to enter public office.

\section{Non-Governmental Organisations and Analysis of Female Participants in Local Level Governance}

In the view of Long (2002), NGOs are mostly self-governing, not-for-profit or voluntary development organisations that are geared towards improving the quality of life of disadvantaged people or organisations especially those not benefiting adequately and directly from government development initiatives. In some cases, they work on behalf of a government, though not under direct control of any government department. Their agendas are based on the philosophical orientation that underpins the establishment of the organisation.

Hudock (1999) and Moyo (2000), for instance, classify NGOs into: service providers, intermediary, advocacy and relief NGOs. The service provider NGOs are those which provide; training services, capacity building, consultancy, research, at the community level, and engage in service delivery for the needy, such as, refugees and flood victims. The intermediary NGOs; liaise with funding agencies and assist grassroots organizations in securing funds and other assistance for development activities. The advocacy NGOs serve as advocates for; the underprivileged, disadvantaged, women, especially widows and street children. NGOs provide relief supplies to communities or countries affected by flood, earthquakes, famine and disease outbreaks. They also give technical assistance in a form of training, fundraising strategies, proposal writing, to make local organisations to run their own activities and make them self-reliant.

Snavely and Desai (2001) aptly observe that decentralisation of authority to local level government and the growing capacity and stability of community level NGOs all have the potential to boost the ability of a community's residents especially women to take control of their lives and improve their communities. Orbista (2012) agrees with Snavely and Desai (2001) with the position that; NGOs in local governance have the potential to improve the communities and influence the provision of benefits to poor residents most of whom are women. 
However, in their research the Federation of Canadian Municipalities (FGM) (2004) notes that the issue of women involvement and local governance still points to the fact that there is a need for "critical mass" of women elected to government so that public policy and processes can be shaped to provide governance that is more responsive to women. The paucity of literature on the field furthers attests to the fact that NGOs are yet to have a breakthrough on the proverbial "glassing ceiling." In this direction as the members of women in local governance through the efforts of NGOs are still abysmally low especially in Northern, Ghana (Amoako, 2011), there is the need for a thorough examination of the issue of NGOs support on the one hand and women's participation in local governance on the other hand.

\section{Contributions of NGOs towards Female Participation in Local Government within Tamale Metropolis}

\section{Financial Support}

Snavely and Desai (2001) argued in their study that NGOs are actors and conduits between the citizens and the local governance structures. They therefore point to the importance of the involvement of NGOs in local governance their relevance for the improvement of communities. Moreover, NGOs influence the provision of benefits to poor residents most of whom are women. Their position confirms and justifies the objectives and findings of this study. For instance the following NGOs namely; NORSAAC, CAMFED and Action Aid Ghana work for and contribute toward the participation of women in local governance in the Tamale Metropolis. One hundred and thirty eight (92\%) of the respondents mentioned that NORSAAC, CAMFED and Action Aid Ghana played a key role in ensuring the participation of women in local governance in the Tamale Metropolis. They stated that the NGOS give financial support to the women to help them contest for office in the Metropolis.

\section{Education, Training and Creating Platforms for Campaigns during Elections}

NORSAAC, CAMFED and ActionAid Ghana provide education and training programmes for women interested in contesting local level elections before election time. Thirty (20\%) of the respondents stated that the three NGOs provided education and training for women to enable them vie for office at the local level before elections take place in the Metropolis over the years. In a FGD with women in local governance, they said:

The NGOs provide us with education and training programmes, leadership and empowerment skills that build our self-confidence, and 
engage traditional authorities in advocacy programmes so we can have a chance to compete with the men. It appears that is the reason why we are currently serving in our capacities here in the assembly.

Aside the education and training programmes, the three NGOs create platforms for women who wish to campaign during local level elections. The women are able to market themselves to the electorates during such platforms. Fifteen (10\%) of the respondents mentioned that the NGOs created platforms for women to campaign during local level elections. Figure 1 shows the number of women NORSAAC, CAMFED and ActionAid Ghana are able to support during the 2015 local level elections in the Tamale Metropolis.

\section{Figure 3: Number of women NORSAAC, CAMFED and ActionAid Ghana are able to support during the 2015 local level elections in the Tamale Metropolis}

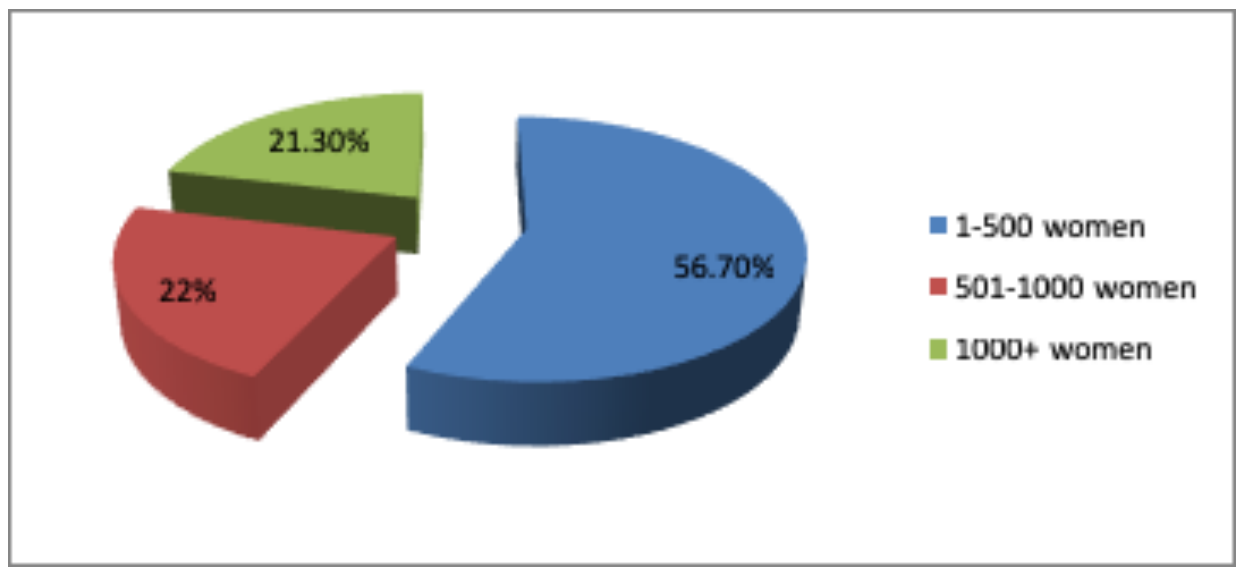

Source: Field data (2017)

Figure 1 indicates that NORSAAC, CAMFED and Action Aid Ghana have been contributing to improving the mainstreaming of women involvement in local governance in the Tamale Metropolis. Respondents who said the NGOs supported up 500 women were $65.7 \%$, those who mentioned that the NGOs supported up to 1000 women were $22 \%$ while those who mentioned above one thousand women through their activities in the 2015 local level elections in the Metropolis were $21.3 \%$.

\section{Advocacy Support Programmes}

Apart from education, training and creating of platforms for campaigns during elections, NORSAAC, CAMFED and Action Aid Ghana also undertake advocacy support programmes towards women's participation in local governance. In confirming this, thirty (30) respondents representing twenty percent (20\%) 
mentioned that the three NGOs undertook advocacy programmes to have more women participation in local governance before 2015 and during the 2015 local level elections. Table 4 shows the number of advocacy support programmes the NGOs undertook in the 2010 and 2015 district level elections.

Table 4: Advocacy support programmes undertaken by NORSAAC, CAMFED and ActionAid Ghana undertook in the 2010 and 2015 district level elections

\begin{tabular}{|l|l|l|l|l|}
\hline Election year & NORSAAC & CAMFED & ActionAid Ghana & Total \\
\hline 2010 & 35 & 23 & 15 & 73 \\
\hline 2015 & 52 & 30 & 21 & 103 \\
\hline Total & 87 & 53 & 36 & 176 \\
\hline
\end{tabular}

Source: Field data (2017)

The table shows that in the 2010 district level election, the three NGOs conducted a total of 73 advocacy support programmes in aid of upping female inclusivity in local governance in the Tamale Metropolis. In the 2015 district level election, a total of 103 advocacy support programmes were organised by the three NGOs. This indicates that the number of advocacy activities increased by 30 more advocacy activities in the 2015 election. The number of advocacy support activities for the two elections totalled 176.

\section{Gender Right-Based Awareness Programmes}

The three NGOs in the Tamale Metropolis undertake rights-based awareness programmes in support of the participation of women in local governance. Fifteen $(10 \%)$ of the respondents mentioned that the NGOs organised gender right-based awareness programmes for women to enlighten them on their ability to vie for office at local governance structures. Equally, the awareness extends to that of their men counterparts for the need to allow their females to vie for public office at the local level. In a FGD with staff of an NGO which supports women's participation in local governance, they said:

We give right-based guidelines to those who want to participate in local level decision making. We particularly let them know that they have the same right as men to seek public office. We also give them training on presentation, social and communication skills to enable them present their ideas well. 


\section{CONCLUSION AND RECOMMENDATIONS}

The analysis of the above data confirm the position indicated in the literature that women have been disadvantaged in their political participation even at the local level of government as in the Tamale Metropolis. This called for the intervention of NGOs, such as, NORSAAC, CAMFED and ActionAid Ghana. These NGOs support women in their bid to participate in local governance through financial support and logistics to help them contest for office, provided education and training for the women on decision making and politics to enable them vie for office, created platforms for women to campaign during local level elections, undertook advocacy programmes to have more women involvement and participation in governance at the local level and organised gender right-based awareness programmes for women to enlighten them on their ability to vie for office at local governance structures. The factors which hinder women's participation are: financial constraints, lack of self-confidence, lack of political skills and knowledge, women's household responsibilities, lack of support from their colleague women, lack of support from government, religion and illiteracy. The mitigation measures women themselves have to take to remove these barriers are: women embracing educational and training opportunities; women should work hard in resource mobilisation to enhance their campaigns and electoral fortunes and women already in local governance should mentor their colleague women outside.

Thus, the following are recommended: promotion of favorable environment for both men and women. Political parties and government should create an enabling political environment for both men and women to be able to contest elections at the local level. Political parties should not just support men to contest against women but look out for competence irrespective of whether the candidate is male or female. Government, on the other hand, should ensure that the laws that pertain to electoral process are duly followed so that those who will violate them especially, using abusive language and violent behaviours in intimidating women face the full rigors of the law.

Secondly, promotion of the education and training of women in Tamale Metropolis. Illiteracy, with its accompanying tenet, ignorance, are the basic contributory factors to social, economic and political inequality and underdevelopment among the women folk albeit their male counterparts. Since, this study revealed that the majority of women in the study area could not participate in local politics and governance because they were illiterates, it is recommended that adequate education and training programmes should be implemented for them by Government, the MGCSP, NGOs, academic institutions and other civic educators. General but especially political literacy is paramount for effective political participation. 
More importantly, the capacity of the few women in local government structures should be built.

Well-designed programmes should be put in place to build the capacities and skills of the few women in the local governance system and other decentralised structures in the district. These programmes will help to equip the women with knowledge and leadership skills that will boost their confidence and ensure effective inclusion in the decision-making process of the Tamale Metropolis.

\section{References}

ABANTU (2003). Positioning Women and Their Concerns in Governance Processes. ABANTU for Development IBIS: Education for Development. Accra, Ghana.

Abubakari, A., Mohammed, A.P. and Issah, E. (2014). Examination of Barriers to Women Participation in Local Governance in Savelugu/Nantong Municipality, Ghana.International Journal of Economics, Commerce and Management 2(4), pp 40-64.

Abdul-Razak, M. (2010). "The Challenges of Women Participation in Local Governance: The Case of Accra and Tamale Metropolitan Assemblies”. (Master in Philosophy thesis, University of Bergen-Norway).

Adatuu, R. (2017). Gender, Political Culture and Sustainable Democracy in Ghana: A Comparative Study of Three Capitals. UDS International Journal of Development. 4 (2), pp. 25-46.

Agbalajobi, D.T. (2009). Women's Participation and the political process in Nigeria: Problems and Prospects. Thesis submitted to the Department of Political Science, College of Management Sciences, Redeemer's University (RUN), Redemption City, Ogun State, Nigeria (unpublished).

Allah-Mensah, B. (2005). Women in Politics and Public Life in Ghana. Accra, Ghana: Freidrich Ebert Stiftung.

Amoako, E.E. (2011). 'The Performances of Women Candidates in the 2010 District Level Elections in Northern, Upper East and Upper West Regions of Ghana-The Electorates' Perspectives'. NORSAAC, CODAC, IBIS GHANA REPORT.

Apusigah, A. A. and Adatuu, R. (2017). Enhancing Women's Fortunes in Ghanaian Electoral

Politics: Is a 50/50 Campaign Realistic? Ghana Journal of Development Studies, 14(2), pp. $43-62$. 
Awal, A.M. (2015). Elected Women in Northern Region. Available online on http:// www.norsaac.org/wp-content/uploads/2016/o1/Press-release-on-2015government-appointment-for-DA.pdf. Accessed on 4th December, 2017.

Baveng, T.B. (2011). One Out of Sixty-Four: The Paucity of Women's Representation in Local Government Politics in Ghana: The Case of Tamale Metropolitan Assembly. Thesis submitted in Partial Fulfilment of the Requirements for obtaining the Degree of Master of Arts in Development Studies Ghana.

Coalition on the Women's Manifesto for Ghana (2004). The Women's Manifesto for Ghana. Congressional Quarterly Inc.: Washington D.C, USA.

Deku, S.A (2005). Participation of women in politics in Ghana: A case study of Jamestown. (Unpublished Bachelors' Project) University of Ghana, Legon.

Dolphyne, F.A. and Ofei-Aboagye, E. (2001). Experiences in Capacity-Building for Ghanaian Women (end). Asempa Publishers, Christian Council of Ghana, Accra: pp. 74-81.

Federation of Canadian Municipalities. (2015). Removing the Barriers to Young Women's Participation in Local Government. Freidrich Ebert Stiftung. hptt:www.ipu.org/pdf/publications/wammap12_en.pdf. Retrieved on 23rd July, 2016.

Hamah, V. (2015). Women's participation in Ghanaian politics: An Assessment of the opportunities and limitations (unpublished). Dissertation submitted to the University of Ghana, Legon, in partial fulfilment of the requirements for the Award of MA Social Policy Studies Degree. Accra, Ghana.

Hudock, A.C. (1999). NGOs and Civil Society: Democracy by Proxy? Cambridge: Polity Press.

Ihemeje, G. (n.d.). The need for participation of women in local governance: A Nigerian discourse International Journal of Educational Administration and Policy Studies. 5(4), pp. 59-66.

Khan, M.M.R. and Ara, F. (2006). Women, Participation and Empowerment in Local Government: Bangladesh Union Parishad Perspective. Asian Affairs, 29(1), 7392. CDBR Publication.

Long, C. (2001). Participation of the Poor in Development Initiatives: Taking Their Rightful Place, London: Earthscan Publications Ltd.

Mahamadu, A. (2010). The Challenges of Women Participation in Local Governance:

Nelson Mandela Metropolitan University, Eastern Cape, South Africa (Unpublished). 
Moyo, S. (2000). The Structure and Characteristics of NGOs. In Moyo, S., Makumbe, J. and Raftopoulos, B. (eds). NGOs, the State and Politics in Zimbabwe, Harare: SAPES Books, pp. 4761.

Nelson, B. J. and Chowdhury, N. (1994). (eds). Women and Politics Worldwide. Yale University Press: New Haven and London, UK.

Orbista, C. (2012). NGOs Participation in Local Governance in the Philippines. A thesis submitted in fulfilment of the requirements for the degree of Master of Arts in Political Science in the University of Canterbury, New Zealand (Unpublished).

Ocran, R.K. (2014). Women's Political Participation: a Comparative Study on Ghana and Tanzania. International Master's Degree Program in Border Crossings: Global and Local Societies in Transition Faculty of Social Sciences, University of Eastern Finland (unpublished).

Ofei-Aboagye, E. (2000). Promoting the Participation of Women in Local Governance and Development: The case of Ghana Institute of Local Government Studies, Legon, Ghana.

Parliamentary Centre (2009). Gender Training Manual for the Parliament of Ghana. 255 Albert St., Suite 802. Ottawa Ontario KIP 6A9 CANADA.

Parry, G., Moyser, G. and Day, N. (1992). Political Participation and Democracy in Britain. Cambridge: Cambridge University Press.

Quansah, J.Y.D. and Essien, D. (2014). Women participation in the local governance: A case of Tamale Municipality in the Northern Region of Ghana. International Journal of Social Science and Humanities Research, 2(3), pp. 216-224.

Shamim, I. and Kumar, R. (2002). Gender and Local Governance A New Discourse in Development. Centre for Women and Children Studies Dhaka, Bangladesh \& Centre for Social Research New Delhi, India.

Shiraz, S. (2015). The participation of women in politics in Ghana: The case of Tamale as a Muslim community. Submitted to the University of Ghana in Partial Fulfilment of the Requirement for the Award of a Master of Philosophy in Political Science.

Snavely, K. and Desai, U. (2001). Mapping local government-nongovernmental organization interactions: A conceptual framework. Journal of Public Administration Research and Theory, 11(2), pp. 245-264.

TAMA (2009). Tamale Metropolitan Area Profile. Tamale Metropolitan Assembly.

Uphoff, N. (1986). Local Institutional Development: An Analytical Source Book with Cases. Oakwood: Kumarian Press. 
World Bank (2001). .Attacking Poverty. New York: Oxford University Press.

Yartey, L.A. (2012). Women in Ghanaian Politics: A Case Study of the Fourth Republic. A Dissertation Submitted to the Department of Political Science and International Relations, College of Development Studies, Covenant University, Ota (unpublished). 